\title{
Ultrastructure of the mature spermatozoon of Eubothrium rugosum (Batsch, 1786) with a re-assessment of the spermatozoon ultrastructure of Eubothrium crassum (Bloch, 1779) (Cestoda: Bothriocephalidea)
}

\author{
M. BRUŇANSKÁ ${ }^{1}$, H.-P. FAGERHOLM ${ }^{2}$, J. NEBESÁŘOVÁ ${ }^{3}$, B. KOSTIČ $\check{C}^{1}$ \\ ${ }^{1}$ Parasitological Institute, Slovak Academy of Sciences, Hlinkova 3, 04001 Košice, Slovak Republic, \\ E-mail:brunan@saske.sk; ${ }^{2}$ Laboratory of Aquatic Pathobiology, Department of Biology, Åbo Akademi University, \\ Artillerigatan 6, FIN 20520, Åbo, Finland; ${ }^{3}$ Institute of Parasitology, Biology Centre of the Academy of Sciences \\ of the Czech Republic, Branišovská 31, 37005 České Budějovice, Czech Republic
}

\begin{abstract}
Summary
The ultrastructure of the mature spermatozoon of the bothriocephalidean tapeworm Eubothrium rugosum, a parasite of the burbot, Lota lota (L.), was studied by transmission electron microscopy for the first time. In addition, spermatozoon ultrastructure of Eubothrium crassum has been re-assessed. New is the finding, that the mature spermatozoa of both species of the genus Eubothrium exhibit essentially the same general morphology. They are filiform cells tapering at both extremities, and they possess the two axonemes with 9+"1" pattern of Trepaxonemata, attachment zones, a nucleus, cortical microtubules (CMs), electron-dense granules, and a single crested body. Structural polymorphism of the CBs has been found within the two Eubothrium species for the first time. The anterior ring of electron-dense tubular structures surrounding a single axoneme marks the border between the two defined regions, region I and region II of the spermatozoon. This unique feature has only been observed in the Bothriocephalidea. The anuclear axoneme region II of Eubothrium spermatozoa fluently verges into a nuclear region III. The posterior part of the spermatozoon contains one-axoneme, few CMs and a posterior extremity of the nucleus that subsequently disappears. The posterior extremity of the male gametes of the genus Eubothrium exhibits elements of a disorganized axoneme which characterize also spermatozoa of the family Triaenophoridae. Discussed are interspecific similarities and differences between the spermatozoa of the two Eubothrium species as well as between these and other Eucestoda.
\end{abstract}

Keywords: ultrastructure; spermatozoon; Eubothrium; Bothriocephalidea; Cestoda

\section{Introduction}

Ultrastructural characters of the spermatozoa are frequently used not only to highlight structural and functional features but also as a basis for phylogenetic considerations of parasitic Platyhelminthes (Neodermata) (Hoberg et al., 1997, 2001; Justine, 1998, 2001, 2003; Olson et al., 2001). Recent reviews on the ultrastructure of the cestode spermatozoa, based on a large number of species, provide detailed information on various sperm components and their development (Bâ \& Marchand, 1995; Justine, 1998; Watson, 1999; Bruňanská, 2010).

Seven taxa of three families (Bothriocephalidae, Echinophallidae, Triaenophoridae) within the Bothriocephalidea have been studied so far (Świderski \& Mokhtar-Maamouri, 1980; Bâ et al., 2007; Levron et al., 2006a, c; Šípková et al., 2010; Bruňanská et al., 2002; Levron et al., 2005). Data available show, that the ultrastructural organization of the mature spermatozoon of E. crassum differs from that in other bothriocephalideans. Therefore, the subject of the present study is to explore the fine structure of the mature spermatozoon of Eubothrium rugosum (Batsch, 1786), the type species of the genus. Furthermore, a re-investigation of the mature spermatozoa of $E$. crassum was made to unravel additional information of the spermatozoon ultrastructure of tapeworms of the genus Eubothrium.

\section{Materials and Methods}

Specimens of Eubothrium rugosum (Batsch, 1786) (Cestoda: Bothriocephalidea) were collected from burbot, Lota 


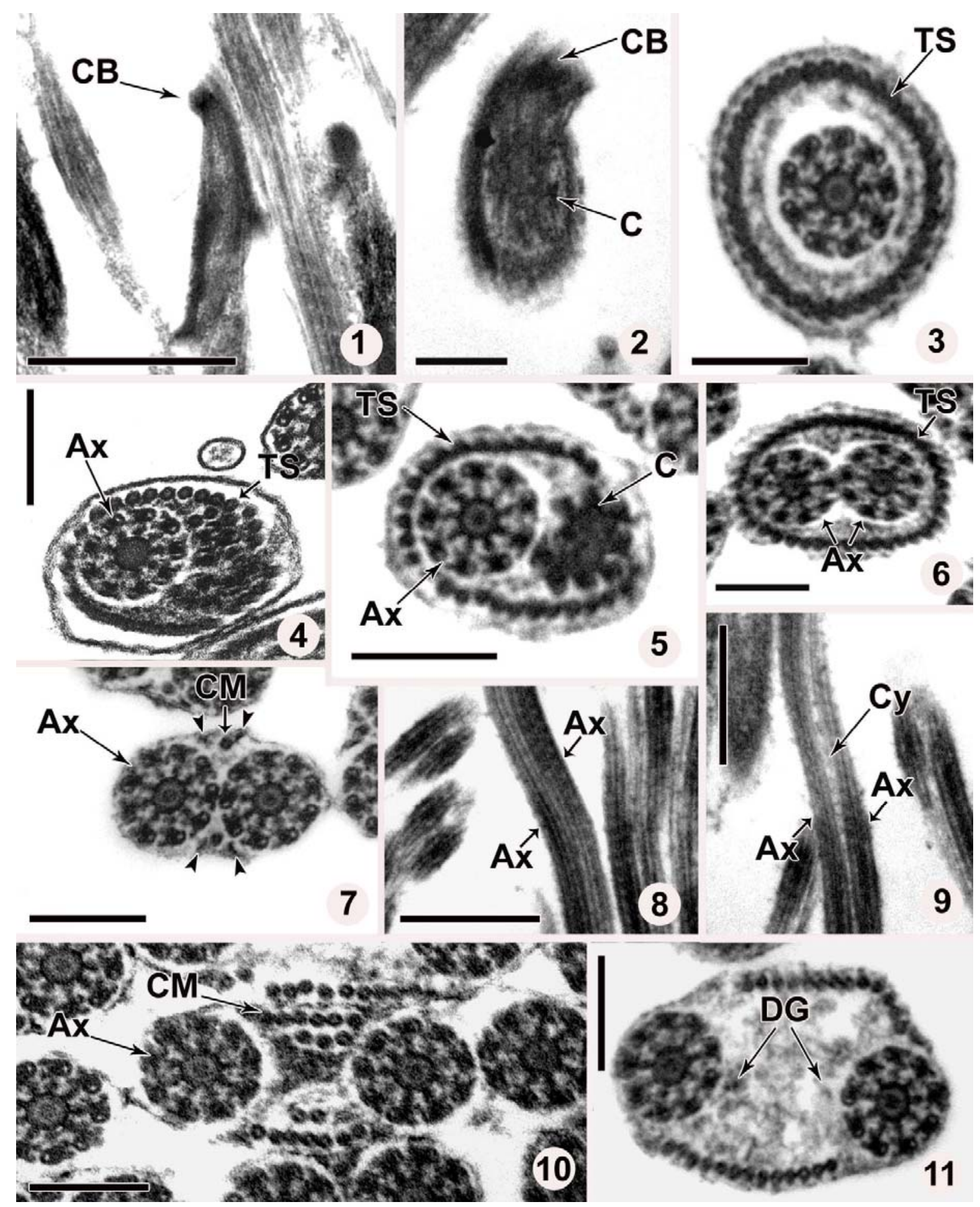

Fig. 1. Longitudinal section of the anterior extremity of the mature spermatozoon of Eubothrium rugosum. $\mathrm{CB}-$ crested body. Bar $=1 \mu \mathrm{m}$; Fig. 2. Cross-section of the anterior extremity of the spermatozoon. $\mathrm{C}-$ centriole; $\mathrm{CB}-$ crested body. $\mathrm{Bar}=250 \mathrm{~nm}$; Fig. 3. Cross-section of region I with the ring of electron dense tubular structures (TS). Bar $=200 \mathrm{~nm}$; Fig. 4. Cross-section of the transition zone between the regions I and II documented an incresed number of tubular structures (TS) in the vicinity of the axoneme (Ax). Bar $=200 \mathrm{~nm}$; Fig. 5. Serial cross-section of the transition zone between regions I and II showing the centriole of the second axoneme (C). The ring of electron dense tubular structures (TS) is disorganized. Bar $=200 \mathrm{~nm}$; Fig. 6. Serial cross-section to those shown in Figs. 4 and 5, with the two axonemes (Ax) surrounded by a ring of tubular structures (TS). Bar $=200 \mathrm{~nm}$; Fig. 7. Attachment zones (arrowheads) and cortical microtubules (CM) in the region II

of the spermatozoon. Ax - axoneme. Bar $=200 \mathrm{~nm}$; Fig. 8. Longitudinal section of region II with the two tightly packed axonemes (Ax). $\mathrm{Bar}=1 \mu \mathrm{m}$; Fig. 9. Longitudinal section of region II with the two axonemes (Ax) situated in the increased volume of the cytoplasm (Cy).

$\mathrm{Bar}=1 \mu \mathrm{m}$; Fig. 10. Cross-section of the region II. Note two parallel rows of CMs arranged opposite side. Bar $=200 \mathrm{~nm}$; Fig. 11 Cross-section of the posterior part of region II with the two axonemes. DG - electron-dense granules. Bar $=200 \mathrm{~nm}$. 
lota (Linnaeus, 1758), from the Rybinsk water reservoir, Yaroslavl District, Russia. Living worms were cooled in $0.9 \% \mathrm{NaCl}$ solution and then fixed in $2.5 \%$ glutaraldehyde in $0.1 \mathrm{M}$ cacodylate buffer, $\mathrm{pH} 7.2$ at $4^{\circ} \mathrm{C}$. Mature and pregravid proglottids were separated, rinsed in the same buffer and post-fixed in $1 \% \mathrm{OsO}_{4}$ at $4{ }^{\circ} \mathrm{C}$ for $2 \mathrm{~h}$, followed by dehydration in graded alcohol series and embedding in Spurr. A series of ultrathin sections were cut using a Leica Ultracut UCT ultramicrotome, placed on copper grids and double-stained with uranyl acetate and lead citrate. The grids were examined in a JEOL 1010 transmission electron microscope operated at $80 \mathrm{kV}$. Data concerning $E$. crassum specimens studied are detailed in Bruňanská et al. (2002).

\section{Results}

Mature spermatozoa (gametes), originating from the testes and seminal vesicles of Eubothrium rugosum were investigated. In addition, male gametes of E. crassum have been re-addressed. The gametes of both Eubothrium species are filiform cells, tapering at both extremities. Five different characteristic regions $(\mathrm{I}-\mathrm{V})$ can be distinguished anteroposteriorly.

Region I (Figs. 1 - 4, 18I) corresponds to the anterior part of the spermatozoon, exhibiting one axoneme. A lateral electron-dense projections, $120 \mathrm{~nm}$ thick, create the helicoidal crested body of the spermatozoon (Figs. 1, 2). The distance between the two projections of the crested body is about $600 \mathrm{~nm}$ (Fig. 1). In E. rugosum, the crested body consists of electron-dense tubular structures, surrounding the centriole (Fig. 2) and anterior part of the axoneme having the $9+$ " 1 " trepaxonematan character. At the end of region I, electron dense tubular structures create a ring, which surrounds the central axoneme (Fig. 3) in both Eubothrium species. Here, the diameter of the spermatozoon is $390 \mathrm{~nm}$. In the transition zone between the region I and II, the number of electron dense tubular structures markedly increases (Fig. 4).

Region II (Figs. $5-11,18 \mathrm{II})$ is characterized by the two axonemes in both Eubothrium species. Firstly, the centriole of the second axoneme is formed (Fig. 5). Simultaneously, the shape of the spermatozoon becomes more ovate in cross section. In E. rugosum, the two axonemes were only very rarely found within a closed ring of electron dense tubular structures (Fig. 6). As a rule, the ring of electron dense tubular structures is interrupted, and disappears completely when the second axoneme has appeared (Fig. 7). Both axonemes are tightly packed within a small amount of cytoplasm, containing the two cortical microtubules (CMs) situated opposed to each other (Figs. 7, 8). Four small electron-dense elements, the attachment zones, are situated on both sides of each axoneme (Fig. 7). The diameter of the spermatozoon is about $380 \mathrm{~nm}$. Subsequently, the volume of cytoplasm and the number of CMs gradually increases. The cytoplasm contains electron-dense
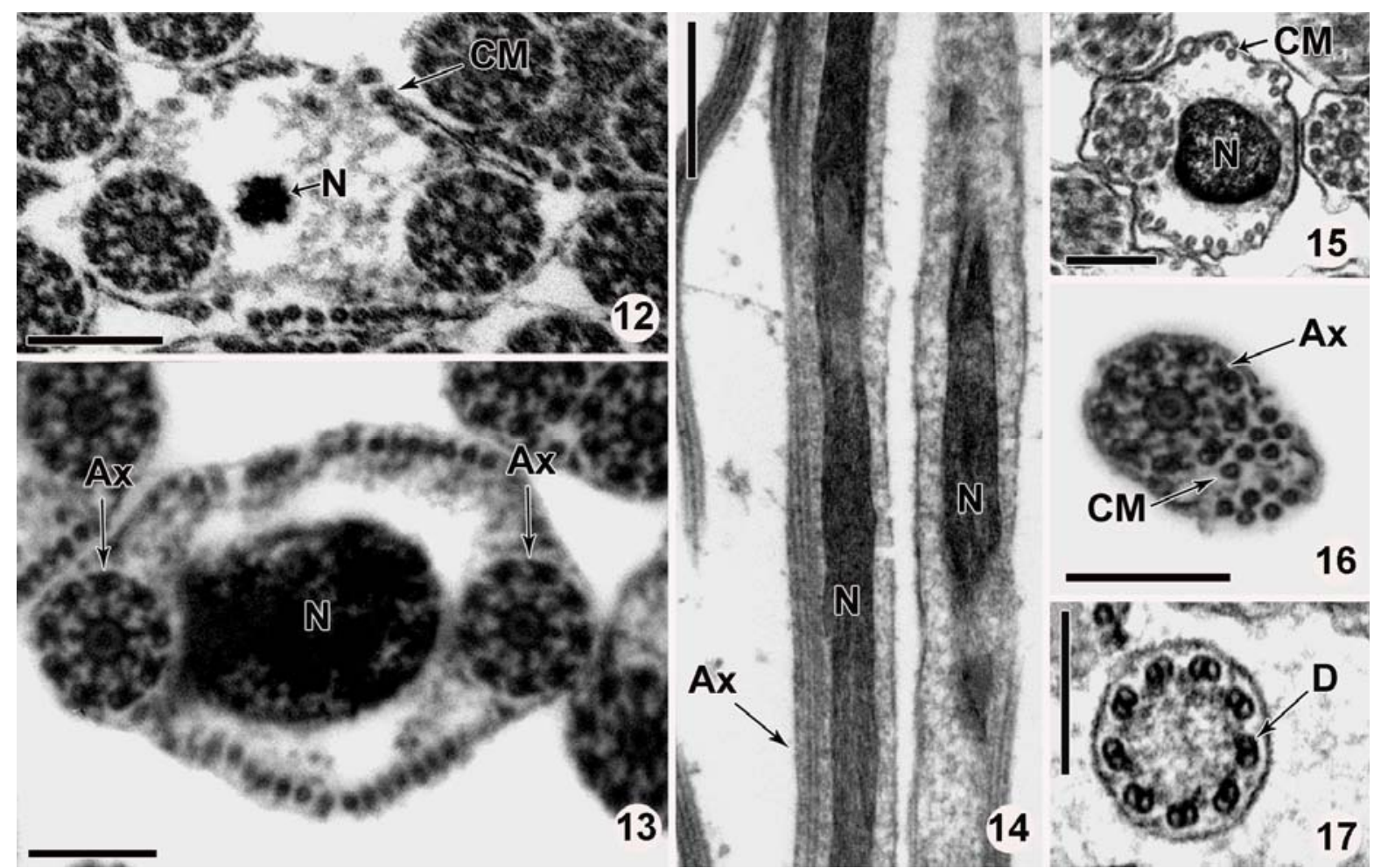

Fig. 12. Cross section of the anterior part of region III. CM - cortical microtubules, N- nucleus. Bar = 200 nm; Fig. 13. Cross-section of the central part of the region III. Ax - axoneme, $\mathrm{N}$ - nucleus. Bar $=200 \mathrm{~nm}$; Fig. 14 Longitudinal section of region III. Ax - axoneme, $\mathrm{N}-$ nucleus.

Bar $=1 \mu \mathrm{m}$; Fig. 15. Cross-section of region IV with one axoneme, nucleus $(\mathrm{N})$ and a reduced number of cortical microtubules $(\mathrm{CM})$. Bar $=200 \mathrm{~nm}$; Fig. 16. Cross-section of the posterior part of region IV. Note the CMs arranged at the periphery of the cell, and additional CMs scattered in the cytoplasm. Ax - axoneme. Bar $=200 \mathrm{~nm}$; Fig. 17. Disorganization of the axoneme into doublets (D) in the region V of the spermatozoon. Bar $=200 \mathrm{~nm}$. 


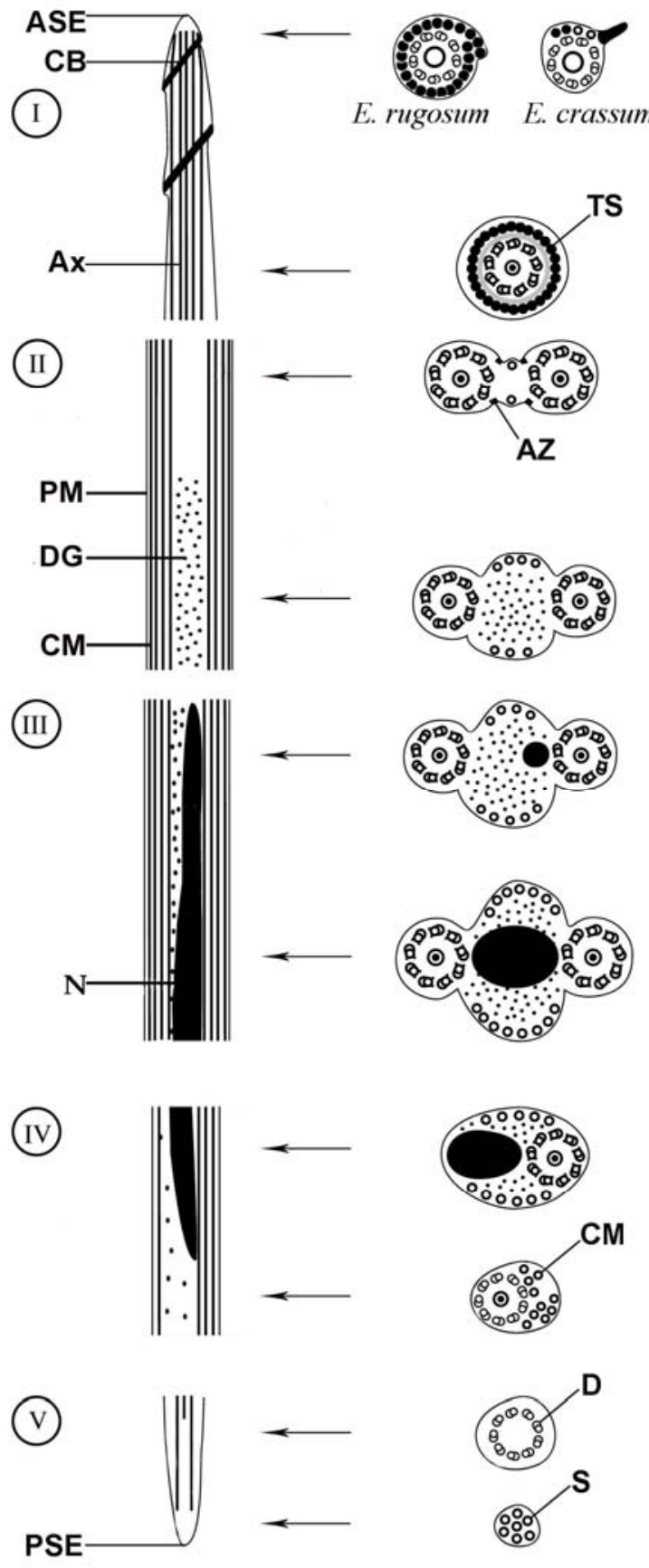

Fig. 18. Schematic reconstruction of the mature spermatozoon of E. rugosum and/or E. crassum.

$\mathrm{Ax}$ - axoneme, AZ - attachment zones, ASE - anterior spermatozoon extremity, CB - crested body, CM - cortical microtubules,

$\mathrm{D}$ - doublets, DG - dense granules, $\mathrm{N}$ - nucleus, $\mathrm{PM}$ - plasma membrane, PSE - posterior spermatozoon extremity, $\mathrm{S}$ - singlets, $\mathrm{TS}$ - tubular structures.

granules (Figs. 9, 10, 11). The CMs are now arranged in two opposite rows. The CMs have a thin membrane and electron-lucent centre. Occasionally, a second short row of $3 \mathrm{CMs}$ parallel with the peripheral CMs, was observed in some cross sections of region II of mature spermatozoa of E. rugosum (Fig. 10). The diameter of the spermatozoon is about $530 \mathrm{~nm}$ at the end of region II. Each row of CMs is composed of up to $14-15$ elements (Fig. 11).

Region III (Figs. $12-14,18 \mathrm{III})$ is the nucleated part of the spermatozoon with the two axonemes. In cross sections studied, the nucleus is ovate (oval-shaped), situated centrally between the axonemes. The anterior extremity of the nucleus is eccentrically situated (diameter small, about 60 $\mathrm{nm}$ ) (Fig. 12). More posteriorly, the nucleus has a concentric position and its size increases progressively up to 420 nm (Figs. 13, 14). The nucleus contains strands of a fine fibrilar material. The CMs form 2 opposite rows under the plasma membrane and come into close contact with it. The cytoplasm of the spermatozoon exhibits electron-dense granules. The diametre of the cell is $860 \mathrm{~nm}$.

Region IV (Figs. 15, 16, 18IV) contains only one axoneme, the nucleus and CMs. The diameter of the spermatozoon and its nucleus are reduced to one half when compared with the central part of the region III. Two fields of CMs are composed of some 5 elements (Fig. 15). At the end of region IV of the spermatozoon the nucleus disappears, one axoneme and some scattered CMs are situated within a small amount of cytoplasm (Fig. 16).

Region $V$ (Figs. 17, 18V) is characterized by progressive disorganization of the axoneme. The central core disappears and doublets lose their arms (Fig. 17). Posteriorly, doublets become disorganized and are finally transformed into singlets. The diameter of the posterior extremity of the gamete is about $140 \mathrm{~nm}$.

\section{Discussion}

The mature spermatozoa of Eubothrium rugosum and Eubothrium crassum exhibit essentially the same general morphology. They contain the two axonemes with their attachment zones, a nucleus, an anterior ring of tubular electron-dense structures, cortical microtubules (CMs), electron-dense granules, and a single crested body (CB). The interspecific differences concern the structure of the CB.

Generally, the $\mathrm{CB}$ is absent in the mature spermatozoa of the evolutionary older cestodes, e.g. Gyrocotylidea and Amphilinidea (Rohde \& Watson, 1986; Xylander, 1989), Caryophyllidea (Świderski \& Mackiewicz, 2002; Gamil, 2008; Miquel et al., 2008; Bruňanská, 2009, 2010), Spathebothriidea (Bruňanská et al., 2006; Bruňanská \& Poddubnaya, 2010), Diphyllobothriidea (Levron et al., 2006b, 2009), Haplobothriidea (MacKinnon \& Burt, 1985), or Trypanorhyncha (Miquel \& Świderski, 2006; Miquel et al., 2007b). The CB occurs in the more primitive two-axoneme spermatozoa of the Bothriocephalidea (Šípková et al., 2010), Tetraphyllidea - Onchobothriidae (Mokhtar-Maamouri \& Świderski, 1975), Tetraphyllidea Phyllobothriidae (Mahendrasingam et al., 1989), and Proteocephalidea (Bâ \& Marchand, 1994; Sène et al., 1997; Bruňanská et al., 2003a, b, 2004a, b) as well as in the evolved single-axoneme spermatozoa (mainly members of the Cyclophyllidea, see Justine, 1998).

In both Eubothrium species, the CB is spiralized around the anterior part of the spermatozoon, including the cen- 
triolar level, thus resembling other bothriocephalideans (Levron et al., 2005; Levron et al., 2006a; Bâ et al., 2007; Śípková et al., 2010). The CB in E. rugosum consists of electron dense tubular structures, which were found also in Triaenophorus nodulosus and Bothriocephalus scorpii (Levron et al., 2005, 2006a). On the other hand, the CB of E. crassum is an electron-dense structure (Bruňanská et al., 2002; Fig. 18 in the present study) as described in bothriocephalidean Paraechinophallus japonicus (Levron et al., 2006c), Parabothriocephalus gracilis (Šípková et al., 2010), diphyllobothriidean Duthiersia fimbriata (Justine, 1986), in some proteocephalideans or cyclophyllideans (Bruňanská, 2010). Polymorphism of the CBs seems to exist within Eubothrium species.

The taxonomically and phylogenetically interesting ultrastructural features of the spermatozoa in Eucestoda include the number of axonemes, the presence/absence of the attachment zones, an anterior ring of tubular structures, arrangement of cortical microtubules (CMs), and the posterior structures.

The two axonemes of $9+$ " 1 " pattern of the Trepaxonemata (Ehlers, 1984) characterize mature spermatozoa of both Eubothrium species, as well as the Bothriocephalidea, Diphyllobothriidea, Spathebothriidea, Haplobothriidea, Trypanorhyncha, Tetraphyllidea, and Proteocephalidea (Bruňanská, 2010). The two-axoneme-structure is considered a plesiomorphic character of the Eucestoda (Justine, 1998).

The four attachment zones described in the spermatozoa of Eubothrium mark the point of the fusion of the two axonemes with the median cytoplasmic process during spermiogenesis (Bruňanská et al., 2002; the present study). These elements are known also in the spermatozoa of bothriocephalideans B. scorpii (Levron et al., 2006a), $P$. japonicus (Levron et al., 2006c), diphyllobothriideans (Levron et al., 2006b, 2009), trypanorhynchs Dollfusiella spinulifera (Miquel \& Świderski, 2006), Parachristianella trygonis (Miquel et al., 2007b) and cyclophyllidean Joyeuxiella (Ndiaye et al., 2003). The attachment zones were detected during spermiogenesis in the spathebothriideans Cyathocephalus truncatus (Bruňanská et al., 2006) and Didymobothrium rudolphii (Bruňanská \& Poddubnaya, 2010).

A ring of tubular structures marks the end of region I in Eubothrium species and in the mature spermatozoa of the bothriocephalideans $T$. nodulosus (Levron et al., 2005), B. scorpii (Levron et al., 2006a), P. japonicus (Levron et al., 2006c), and P. gracilis (Šípková et al., 2010). Two exceptions are $B$. clavibothrium and $E$. crassum having the ring of tubular structures located in the postnuclear region (Świderski \& Mokhtar-Maamouri, 1980; Bruňanská et al., 2002). Re-assessment of the fine structure of the spermatozoa of E. crassum has shown, however, that a ring of tubular structures encircling the central axoneme at the beginning of the region $\mathrm{V}$ (Bruňanská et al., 2002), actually should be placed at the end of region I. A ring of tubular structures may occasionally encircle the two fully formed axonemes in the spermatozoa of E. rugosum. This new character has been found for the first time in the Eucestoda.

Only one or two CMs are present at the beginning of region II in E. rugosum. Similar pattern characterize the corresponding region of the spermatozoa of the bothriocephalideans (Levron et al., 2005, 2006a, c; Śípková et al., 2010), diphyllobothriideans (Levron et al., 2006b, 2009), spathebothriideans (Bruňanská et al., 2006, Bruňanská \& Poddubnaya, 2010) and trypanorhynchs (Miquel \& Świderski, 2006; Miquel et al., 2007b). This characteristic region has been described in the spermatozoon of $E$. crassum, and designated as region IV (Bruňanská et al., 2002). However, re-assessment of our previous results led us to the conclusion, that ultrastructural characteristics of the spermatozoa of E. crassum and E. rugosum are congruent. Thus, the two tightly packed axonemes originally placed into region IV (Bruňanská et al., 2002) actually belong to the beginning of the region II, and vice versa, the one with one axoneme and nuclear appendix originally placed into region II actually fall into region IV of the spermatozoon of E. crassum.

CMs form two opposite fields in the nuclear region of the spermatozoa (Justine, 1998), and also in the prenuclear two-axoneme region of the spermatozoa of the Spathebothriidea, Bothriocephalidea, Diphyllobothriidea, Haplobothriidea, Trypanorhyncha, Tetraphyllidea, and Proteocephalidea. However, the second row of microtubules parallel with the CMs in the prenuclear two-axoneme region has been described only in the spermatozoa of the bothriocephalidean E. rugosum (the present study) and spathebothriidean Didymobothrium rudolphii (Bruňanská \& Poddubnaya, 2010).

The posterior part of the spermatozoa of both Eubothrium species is characterized by the following structural succession pattern: posterior extremity of the nucleus, reduced number of cortical microtubules, posterior extremity of the axoneme (Bruňanská et al., 2002; the present study). This pattern was described also in bothriocephalidean T. nodulosus (Levron et al., 2005) and may characterise spermatozoa of the family Triaenophoridae. However, spermatozoa of the Bothriocephalidae show remarkable variability in the posterior structure of the male gametes, relating to the sequence: posterior nucleus extremity, axoneme, CMs (Świderski \& Mokhtar-Maamouri, 1980; Bâ et al., 2007, Levron et al., 2006). The structural heterogeneity of the posterior region of the spermatozoa within the Bothriocephalidae seems to restrict the use of this feature as potentially interesting criterion for taxonomy or phylogeny of the Eucestoda.

The present study gives evidence that the spermatozoon of E. rugosum shares the basic ultrastructural and phylogenetically useful characters (the presence of two axonemes and their attachment zones, a single crested body, an anterior ring of electron-dense cortical microtubules, the organization of the two-axoneme region, and the type of the posterior part of the spermatozoon) with the spermatozoon of E. crassum as well as with male gametes of the Triaenophoridae representatives studied till now. Sperma- 
tological data are congruent with conclusions of recent molecular studies. Both approaches support the existence of two independent lineages within the former order Pseudophyllidea: the basal Diphyllobothriidea and the more derived Bothriocephalidea (Waeschenbach et al., 2007; Olson et al., 2008).

\section{Acknowledgements}

We would like to thank Dr. Larisa G. Poddubnaya, Institute of Biology of Inland Waters, Russian Academy of Sciences, Borok, Yaroslavl Region 152742, Russia, for collecting and kindly providing us with specimens of Eubothrium rugosum. We are grateful to the staff of the Laboratory of Electron Microscopy, Institute of Parasitology AS CR, České Budějovice, Czech Republic, for technical assistance. Financial support was provided by the Grant Agency of the Slovak Republic VEGA (project no. $2 / 0018 / 08$ ). The work was realized within a frame of Centre of Excellence for Parasitology (Code ITMS: 26220120022) based on the support of the Operational Programme "Research \& Development" funded from the European regional Development Fund (rate 0.5).

\section{References}

BÂ, C. T., Marchand, B. (1995): Spermiogenesis, spermatozoa and phyletic affinities in the Cestoda. In: Jamieson, B. G. M., Ausió, J., Justine, J. L. (Eds) Advances in spermatozoal phylogeny and taxonomy. Mem. Mus. Natl. Hist. Nat., 166: $87-95$

BÂ, C. T., MARCHAND, B. (1994): Ultrastructure of the spermatozoon of Sandonella sandoni (Cestoda, Proteocephalidea, Sandonellinae). Invert. Reprod. Dev., 25: 9 - 17 BÂ, C. T., BÂ, A., MARCHAND, B. (2007): Ultrastructure of the spermatozoon of Bothriocephalus claviceps (Cestoda, Pseudophyllidea): a parasite of Anguilla anguilla (Fish, Teleostei). Parasitol. Res., 101: 77 - 83. DOI: 10.1007/s00 436-006-0445-z

BRUŇANSKÁ, M. (2009): Spermatological characters of the caryophyllidean cestode Khawia sinensis Hsü, 1935, a carp parasite. Parasitol. Res., 105: 1603 - 1610. DOI: 10.1007/ s00436-009-1599-2

BRUŇANSKÁ, M. (2010): Recent insights into spermatozoa development and ultrastructure in the Eucestoda. In: Lejeune, T., DelvauX, P. (Eds) Human spermatozoa: maturation, capacitation and abnormalities. Nova Science Publishers, Inc., New York, pp. 327 - 354. ISBN: 978-160876-401-3

BruñanskÁ, M., Poddubnaya, L. G. (2010): Spermatological characters of the spathebothriidean tapeworm Didymobothrium rudolphii (Monticelli, 1890). Parasitol. Res., 106: 1435 - 1442. DOI: 10.1007/s00436-010-1822-1 BRUŇANSKÁ, M., NebesÁŘOVÁ, J., SChOlZ, T., FAGERHOLM, H.-P. (2002): Ultrastructure of the spermatozoon of the pseudophyllidean cestode Eubothrium crassum (Bloch, 1779). Parasitol. Res., 88: 285 - 291. DOI: 10.10 07/s004360100392
BruňanskÁ, M., Scholz, T., Dezfuli, B., Poddubnaya, L. G. (2006): Spermiogenesis and sperm ultrastructure of Cyathocephalus truncatus (Pallas, 1781) Kessler, 1868 (Cestoda: Spathebothriidea). J. Parasitol., 92: 884 - 892

BRuŇAnskÁ, M., NebesÁŘovÁ, J., Scholz, T. (2003a): Ultrastructure of the spermatozoon of the proteocephalidean cestode Proteocephalus torulosus (Batsch, 1786). Parasitol. Res., 89: 345 - 351. DOI: 10.1007/s00436-0020757-6

BruňAnskÁ, M., SchOlz, T., IBraheEM, M. H. (2004a): Ultrastructural particularities of the spermatozoon of the cestode Electrotaenia malopteruri (Fritsch, 1886) (Proteocephalidae: Gangesiinae), a parasite of Malapterurus electricus (Siluriformes: Malapteruridae) from the Nile, Egypt. Parasitol. Res., 93: 114 - 120. DOI: 10.1007/s00436-0041109-5

BruŇAnskÁ, M., SchOlz, T., IBraheEM, M. H. (2004b): Ultrastrutural characters of the spermatozoon of the cestode Corallobothrium solidum Fritsch, 1886 (Cestoda: Proteocephalidea), a parasite of the electric catfish Malapterurus electricus. Parasitol. Res., 94: 421 - 426. DOI: 10.1007/s00436-004-126-z

BRuŇANSKÁ, M., SCHOlZ, T., NeBEsÁŘovÁ, J. (2003b): Reinvestigation of the spermatozoon of the cestode Proteocephalus longicollis (Zeder, 1800), a parasite of salmonid fish. Parasitol. Res. 91: 357 - 362. DOI: 10.1007/s0 0436-003-0977-4

EHLERS, U. (1984): Phylogenetisches System der Plathelminthes. Verh. des Naturwiss. Ver. Hamb., 27: 291 - 294

GAMIL, I. S. (2008): Ultrastructural studies of the spermatogenesis and spermiogenesis of the caryophyllidean cestode Wenyonia virilis (Woodland, 1923). Parasitol. Res., 103: 777 - 785. DOI: 10.1007/s00436-008-1040-2

Hoberg, E. P., Mariaux, J., Brooks, D. R. (2001): Phylogeny among the orders of the Eucestoda (Cercomeromorphae): integrating morphology, molecules and total evidence. In: LitTlEWOOD, D. T. J., BRAY, R. A. (Eds) Interrelationships of the Platyhelminthes. Taylor and Francis, London, New York, pp. $112-126$

Hoberg, E. P., MariauX, J., Justine, J. L., Brooks, D. R., WeEkES, P. J. (1997): Phylogeny of the orders of the Eucestoda (Cercomeromorphae) based on comparative morphology: historical perspectives and a new working hypothesis. J. Parasitol., 83: 1128 - 1147

JUSTINE, J.-L. (1986): Ultrastructure of the spermatozoon of the cestode Duthiersia fimbriata Diesing, 1854 (Pseudophyllidea, Diphyllobothriidae). Can. J. Zool., 64: $1545-1548$

JUSTINE, J.-L. (1998): Spermatozoa as phylogenetic characters for the Eucestoda. J. Parasitol., 84: 385 - 408

Justine, J.-L. (2001): Spermatozoa as phylogenetic characters for the Platyhelminthes. In: LiTTLEWOOD, D. T. J., BRAY, R. A. (Eds) Interrelationships of the Platyhelminthes. Taylor and Francis, London, New York, pp. $231-238$ JUSTINE, J.-L. (2003): Ultrastructure des spermatozoïdes et phylogénie des Neodermata. In: CoMBES, C., JourdANE, J. (Eds) Taxonomy, ecology and evolution of metazoan parasites. PUP, Perpignan, pp. 359 - 380 
Levron, C., BruñanskÁ, M., Marchand, B. (2005): Spermiogenesis and sperm ultrastructure of the pseudophyllidean cestode Triaenophorus nodulosus (Pallas, 1781). Parasitol. Res., 98: 26 - 33. DOI: 10.1007/s00436005-0009-7

LEVRON, C., BRUŇANSKÁ, M., PODDUBNAYA, L. G. (2006a): Spermatological characters of the pseudophyllidean cestode Bothriocephalus scorpii (Müller, 1776). Parasitol. Int., 55: 113 - 120. DOI: 10.1016/j.parint.2005.11.055

Levron, C., Bruñanská, M., Poddubnaya, L. G. (2006b): Spermatological characters in Diphyllobothrium latum (Cestoda, Pseudophyllidea). J. Morph., 267: 1110 1119. DOI: $10.1002 /$ jmor. 10460

LeVron, C., Bruñanská, M., KuChta, R., FreEman, M., SCHOLZ, T. (2006c): Spermatozoon ultrastructure of the pseudophyllidean cestode Paraechinophallus japonicus, a parasite of deep-sea fish Psenopsis anomala (Perciformes, Centrolophidae). Parasitol. Res., 100: 115 -121. DOI: 10.1007/s00436-006-0224-x

LEVRON, C., SiTKO, J., SchOlZ, T. (2009): Spermiogenesis and spermatozoon of the tapeworm Ligula intestinalis (Diphyllobothriidae): phylogenetic implications. J. Parasitol., 95: 1 - 9

MACKInNON, B. M., BURT, M. D. B. (1985): Ultrastructure of spermatogenesis and the mature spermatozoon of Haplobothrium globuliforme Cooper, 1914 (Cestoda: Haplobothrioidea). Can. J. Zool., 63: $1478-1487$

Mahendrasingam, S., Fairweather, I., Halton, W. (1989): Spermatogenesis and the fine structure of the mature spermatozoon in the free proglottis of Trilocularia acanthiaevulgaris (Cestoda, Tetraphyllidea). Parasitol. Res., 75: $287-298$

MiQUEL, J., ŚWIDERSKI, Z. (2006): Ultrastructure of the spermatozoon of Dollfusiella spinulifera (Beveridge and Jones, 2000) Beveridge, Neifar and Euzet, 2004 (Trypanorhyncha, Eutetrarhynchidae). Parasitol. Res., 99: 37 - 44. DOI: 10.1007/s00436-005-0094-7

MiQuel, J., EIRA, C., ŚWIDERSKI, Z., CONN, D. B. (2007a): Mesocestoides lineatus (Goeze, 1782) (Mesocestoididae): new data on sperm ultrastructure. J. Parasitol., 93: 545 - 552 MiQuel, J., Świderski, Z, MACKIEWICZ, J. S., IBRAHEEM, M. H. (2008): Ultrastructure of spermiogenesis in the caryophyllidean cestode Wenyonia virilis Woodland, 1923, with re-assessment of flagellar rotation in Glaridacris catostomi Cooper, 1920. Acta Parasitol., 53: 19 - 29. DOI: 10.2478/s11686-008-0013-Z

Miquel, J., ŚwidersKi, Z., NeIFAR, L., EiRA, C. (2007b): Ultrastructure of the spermatozoon of Parachristianella trygonis Dollfus, 1946 (Trypanorhyncha, Eutetrarhynchidae). J. Parasitol., 93: $1296-1302$

MOKHTAR-MAAMOURI, F., ŚWIDERSKI, Z. (1975): Étude en microscopie électronique de la spermatogénèse de deux cestodes Acanthobothrium filicolle benedenii Loennberg,
1889 et Onchobothrium uncinatum (Rud., 1819) (Tetraphyllidea, Onchobothriidae). Z. Parasitenkd., 47: 269-281 Ndiaye, P. I., MiQuel, J., Marchand, B. (2003): Ultrastructure of spermiogenesis and spermatozoa of Taenia parva Baer, 1926 (Cestoda, Cyclophyllidea, Taeniidae), a parasite of the common genet (Genetta genetta). Parasitol. Res., 89: 34 - 43. DOI: 10.1007/s00436-002-0702-8

Olson, P. D., Poddubnaya, L. G., LitTlewood, D. T. J., SCHOLZ, T. (2008): On the position of Archigetes and its bearing on the early evolution of the tapeworms. J. Parasitol., 94: 898 - 904

Olson, P. D., LitTlewood, D. T. J., BrAy, R. A., MARIAUX, J. (2001): Interrelationships and evolution of the tapeworms (Platyhelminthes: Cestoda). Mol. Phylogenet. Evol., 19: 443 - 467

RoHDE, K., WATSON, N. (1986): Ultrastructure of spermatogenesis and sperm of Austramphilina elongata (Platyhelminthes, Amphilinidea). J. Submicrosc. Cytol., 18: $361-374$

SĖNE, A., BÂ, C. T., MARchAND, B. (1997): Ultrastructure of spermiogenesis and the spermatozoon of Nomimoscolex sp. (Cestoda, Proteocephalidea) intestinal parasite of Clarotes laticeps (fish, teleost) in Senegal. J. Submicrosc. Cytol. Pathol., 29: 115 - 124

ŚWIDERSKI, Z., MACKIEWICZ, J. S. (2002): Ultrastructure of spermatogenesis and spermatozoa of the caryophyllidean cestode Glaridacris catostomi Cooper, 1920. Acta Parasitol., 47: $83-104$

ŚWIDERSKI, Z., MOKHTAR-MAAMOURI, F. (1980): Etude de la spermatogénèse de Bothriocephalus clavibothrium Ariola, 1899 (Cestoda: Pseudophyllidea). Arch. Inst. Pasteur Tunis, 57: 323 - 357

Š́́pKovÁ, L., Levron, C., Freeman, M., Scholz, T. (2010): Spermiogenesis and spermatozoon of the tapeworm Parabothriocephalus gracilis (Bothriocephalidea): ultrastructural and cytochemical studies. Acta Parasitol., 55: 58 - 65. DOI: 10.2478/s11686-010-0003-9 Watson, N. A. (1999): Platyhelminthes. In: ADIYODI, K. G., Adiyodi, R. G., JAmieson, B. G. M. (Eds) Reproductive biology of invertebrates. Volume IX, Part A. Progress in male gamete ultrastructure and phylogeny. Oxford IBH Publishing CO. PVT. Ltd. New Delhi, Calcutta, pp. 97-142

WAEschenBACH, A., Webster, B. L., Bray, R. A., LiTTLEWOOD, D. T. J. (2007): Added resolution among ordinal level relationships of tapeworms (Platyhelminthes: Cestoda) with complete small and large subunit nuclear ribosomal RNA genes. Mol. Phylogen. Evol., 45: 311 325. DOI: 10.1016/j.ympev.2007.03.019

XYLANDER, W. E. R. (1989): Ultrastructural studies on the reproductive system of Gyrocotylidea and Amphilinidea (Cestoda): spermatogenesis, spermatozoa, testes and vas deferens of Gyrocotyle. Int. J. Parasitol., 19: 897 - 905 